\title{
A PRISÃO PREVENTIVA E O DESCASO À LEI 12.403/2011
}

\section{Alexandra de Freitas Miacci Dias ${ }^{1}$ Carlos Alberto Antônio Júnior ${ }^{2}$}

Resumo: A prisão preventiva é uma das medidas cautelares previstas no Código Penal Brasileiro (1941) em seus artigos 311 a 316, que tem como fundamento para sua decretação a garantia da ordem pública, garantia da ordem econômica, conveniência da instrução criminal, assegurar a aplicação da lei penal, e o cumprimento de medida protetiva de urgência. O presente artigo demonstra um excesso exorbitante da prisão preventiva, com justificativas incoerentes ao caso concreto, em desacordo com princípios e tratados constitucionais, desencadeando problemas irreversíveis e de proporção ampla, envolvendo o Estado, em seu Poder legislativo, executivo e Judiciário, bem como a administração Penitenciária. Nesse sentido, a lei 12.403/2011 trouxe inovações para o Código de Processo Penal, porém o que se tem visto é o descaso à tal inovação, sendo necessária uma intervenção do Estado, adotando medidas para corrigir a excessiva aplicação, intensificando a efetiva aplicabilidade das outras medidas cautelares diversas da prisão e devolvendo a identidade da prisão preventiva como excepcionalidade ao processo penal.

Palavras-chave: Sistema prisional brasileiro; Prisão preventiva; Medidas cautelares.

\footnotetext{
1 Direito/Universidade do Vale do Paraíba, Brasil. E-mail: le.miacci@gmail.com.

2 Direito/Universidade do Vale do Paraíba, Brasil. E-mail: carlos.alberto.antonio.jr@gmail.com.
} 